\title{
CLONING OF SUCROSE ISOMERASE ENCODING GENE FROM KLEBSIELLA SINGAPORENSIS ISB-36 AND ITS EXPRESSION IN PICHIA PASTORIS
}

\author{
Cao Xuan Bach, Dang Thi Kim Anh, Nguyen Thanh Thuy, Truong Tu Anh, Nguyen Thi Dieu Linh, Vu \\ Nguyen Thanh ${ }^{\bowtie}$
}

Food Industries Research Institute, 301 Nguyen Trai, Thanh Xuan, Hanoi, Vietnam

${ }^{\circledR}$ To whom correspondence should be addressed. E-mail: thanhvn@firi.vn

Received: 23.12 .2019

Accepted: 27.12.2019

SUMMARY

\begin{abstract}
Given potential health benefits including low glycemic index, tooth friendly, suitable to infants, elderly and diabetic patients, isomaltulose was considered as a promising alternative sweetener to sucrose. Due to the presence of liposaccharide endotoxin in Serratia plymuthica CBS 574.44, a Gram-negative bacterium, and minute amount of formaldehyde carried over, purification of isomaltulose requires rigorous controls in industry. To reduce the cost associated with product purification, here we propose the use of recombinant enzyme in isomaltulose production. The mature gene coding for sucrose isomerase synthase (K.SI36.Pall) from Klebsiella singarporensis ISB 36, which isolated from woodborer in Vietnam, was expressed in Pichia pastoris X33. The nucleotide sequence of K.SI36.PalI gene was similar to AY040843.1 of Klebsiella sp. LX3 except one nucleotide $\mathrm{C}^{1025}$ in AY040843.1 replaced by $\mathrm{T}^{1025}$ in K.SI36.Pall. This leads to single amino acid difference in deduced protein sequence (from 342Ser to 342Phe). Furthermore, the addition of two amino acids (Glu and Phe) was observed at N-terminus. The calculated molecular weight of sucrose isomerase from K.SI36.PalI was $67.46 \mathrm{kDa}$ and the $\mathrm{pI}$ was 6.55 . There was one potential glycosylation site at 466Asn. The maximum sucrose isomerase activity in the culture broth reached $36,6 \mathrm{U} \cdot \mathrm{mL}^{-1}$ in $1 \mathrm{~L}$ shake-flask. The purified recombinant enzyme was most active at $40^{\circ} \mathrm{C}$ and $\mathrm{pH}$ 7.0. At the optimum condition, within 6 hours, the enzyme converted $94 \%$ of sucrose in a $40 \%$ sucrose solution into isomaltulose. This was the first study on the expression of sucrose isomerase synthase gene in P. pastoris, and the results showed the efficient conversion of sucrose isomerase recombinant.
\end{abstract}

Keywords: food sweetener, isomaltulose, Klebsiella, Pichia pastorsis, recombinant enzyme, sucrose isomerase.

\section{INTRODUCTION}

Although playing the most important role in the food industry as a natural sweetener, sucrose, or table sugar, may cause negative effects, such as obesity, dental caries, heart diseases and is not suitable for people with diabetes (Lina et al., 2002). Isomaltulose, a structural isomer of sucrose has been found as a promising alternative. Unlike other sucrose substitutes, isomaltulose can be assimilated by the human body and served as the source of energy (Tiefenbacher, 2017). It is tooth-friendly, promoting the growth of intestine bifidobacteria, causing low glycemic response and suitable for diabetic patients, elderly and infants(Linaet al., 2002). In the food industry, isomaltulose is the precursor for the production of isomalt through hydrogenation (BeMiller, 2019).
In nature, isomaltulose occurs in small amounts in sugar cane syrup and honey (O'Donnell, Kearsley, 2012). It can be produced from sucrose by enzymatic rearrangement. The enzyme responsible for the process is termed as sucrose isomerase (EC 5.4.99.110) which catalyzes the conversion of sucrose ( $\alpha$-D-glucopyranosyl-(1-2)- $\beta$-D-fructofuranoside) into isomaltulose (6-O-alpha-D-glucopyranosyl-Dfructofuranose) and various amounts of D-glucose, Dfructose, and trehalulose (1-O-alpha-Dglucopyranosyl-beta-D-fructose) (Véronèse, Perlot, 1998; Véronèse, Perlot, 1999; Xu et al., 2013). Many bacterial species sucrose isomerase producing has been reported, including Serratia plymuthica, Erwinia rhapontici, Enterobacter sp., Klebsiella singaporensis, Raultella planticola, Enterobacter sp., Pantoea dispersa, and Pseudomonas mesoacidophila (Goulter et al., 2012; 
$\mathrm{Mu}$ et al., 2014a). Several of sucrose isomerase coding genes have been cloned, expressed and characterized (Cha et al., 2009; Park et al., 2010; Mu et al., 2014b). In general, sucrose isomerases are functioning in near-neutral $\mathrm{pH}$ and are thermolabile. For example, PalI from Klebsiella sp. LX3 expressed in Escherichia coli DH5 $\alpha$ demonstrated the highest activity at $\mathrm{pH} 6.0$ and $35^{\circ} \mathrm{C}$. The half-life of the enzyme was merely $1.8 \mathrm{~min}$ at $50^{\circ} \mathrm{C}$ (Zhang et al., 2002). Surface display may alter the properties of sucrose isomerase. Sucrose isomerase from Enterobacter sp. FMB-1 expressed in E. coli was the most active at $\mathrm{pH}$ 6.0, while the surface-displayed enzyme in Saccharomyces cerevisiae showed the highest activity at $\mathrm{pH}$ 7.0. The latter was also slightly more stable to the effect of temperature than the one expressed in E. coli (Lee et al., 2011a; Wei et al., 2013).

Industrially, isomaltulose is produced from foodgrade sucrose by using the formaldehyde-inactivated cells of Protaminobacter rubrum (=Serratia plymuthica) CBS 574.44 as biocatalyst and followed by purification and crystallization (Krastanov, Yoshida, 2003; Kawaguti, Sato, 2010; Goulter et al., 2012; Mu et al., 2014b). Although $S$. plymuthica is a nonpathogenic species, due to the presence of liposaccharide endotoxin in the cell wall and formaldehyde used for bacterial inactivation, the purification step should be carried out with rigorous monitoring (Orsi, Sato, 2016). In this study, we propose a new approach, whereas isomaltulose be produced from sucrose using recombinant enzyme expressed extracellularly by Pichia pastoris. The conversion mixture is expected to be free from endotoxin and formaldehyde, and thus reduces the cost for recovery.

\section{MATERIALS AND METHODS}

\section{Microorganism}

Strain Klebsiella singaporensis ISB-36 demonstrating sucrose isomerase activity was previously isolated from the excrement of woodborer Colosternapollinosa sulphurea Heller on Anisoptera costata Korth collected in Bàu Bàng forest station at Bến Cát, Bình Dương, Vietnam (Nguyễn Thanh Thủy et al., 2013). The strain was identified as $K$. singaporensis as it shared $100 \%$ nucleotide homology with the $r p o B$ sequence JX425353 of LMG 23571, the type strain of $K$. singaporensis ( $\underline{\mathrm{JX} 425353.1})$.

\section{Cloning and expression}

A gene coding for mature sucrose isomerase without sequence for signal peptide (K.SI36.PalI) was isolated by PCR amplification reaction from $K$. singaporensis ISB-36 using primer pair SI12-EcoRI (AGC TGA ATT CGC ACC ATC CTT GAA TCA G) and SI13-XbaI-R (TTG TTC TAG ATT ACC GCA GCT TAT ACA C) designed based on the GenBank sequence AAK82938 encoding sucrose isomerase of $K$. singaporensis LX3 (K.LX3.Pall). The location of cleavage sites for signal peptide sequence was predicted using SignalP 4.1 (http://www.cbs.dtu.dk/services/SignalP/). For PCR, HF-Phusion DNA polymerase (Thermofisher, United States) was used. The amplified product was digested with EcoRI and XbaI (Fermentas, United States), purified using GeneJET Gel Extraction kit (Fermentas, United States), and ligated to pPICZ $\alpha \mathrm{A}$ (Invitrogen, United States) previously digested with the same enzymes using T4 ligase (Fermentas, United States). The ligation product was transformed into $E$. coli DH5 $\alpha$ (Invitrogen, United States) by heat shock and spread on LB low-salt agar $(0.5 \%$ yeast extract, $1 \%$ tryptone, $0.5 \% \mathrm{NaCl}, 1.5 \%$ agar, $\mathrm{pH} \quad 7.0$ ) supplemented with $50 \mathrm{mg} / \mathrm{L}$ zeocin (Invitrogen) and incubated at $37^{\circ} \mathrm{C}$. After $24 \mathrm{~h}$, colonies were picked, grown in liquid LB-zeocin and the plasmids were extracted, digested with EcoRI and $X b a$ I to examine the presence of the heterologous inserts.

The pPICZ $\alpha \mathrm{A}$ containing K.SI36.PalI gene from $K$. singaporensis ISB-36 was opened with MssI (Fermentas, United States) and transformed into $P$. pastoris X33 (Invitrogen, United States) using a Micropulser Electroporator (BioRad, United States) according to the manufacturer's instructions. The transformants were selected using YPD-zeocin agar ( $1 \%$ yeast extract, $2 \%$ bacto peptone, $2 \%$ glucose, $1.5 \%$ agar, $100 \mathrm{mg} . \mathrm{L}^{-1}$ zeocin). Purified transformants were grown in expression medium BMM with methanol as the sole carbon source $(100 \mathrm{mM}$ potassium phosphate, $\mathrm{pH} 6.0,1.34 \%$ yeast nitrogen base (YNB, Difco), 0.4 ppm biotin, $0.5 \%$ methanol).

\section{Sucrose isomerase activity assay}

Sucrose isomerase activity was routinely determined based on the formation of reducing sugar (isomaltulose) from the non-reducing precursor (sucrose) using DNS assay (Ghose, 1987). Since Dglucose, D-fructose, trehalulose can be the by-product of the enzymatic rearrangement, the conversion products were assessed by HPLC. Enzymatic 
reactions were carried out in $20 \%$ of sucrose solution in $20 \mathrm{mM}$ sodium phosphate buffer, $\mathrm{pH}$ 7.0. The reaction was performed in $1.5 \mathrm{~mL}$ microtubes at desired temperatures. After $30 \mathrm{~min}$, sucrose isomerase was inactivated by heating at $100^{\circ} \mathrm{C}$ for $10 \mathrm{~min}$ and then the amount of reducing sugar was determined by DNS method. One unit of sucrose isomerase is determined as the amount of enzyme required for conversion of sucrose into $1 \mu \mathrm{mol}$ of reducing sugar per min at a given testing condition. The assay was carried out in triplicate and the mean value was given.

For HPLC analyses, reverse-phase column Cosmosil ODS 5C18MSII (Nacalai Tesque, United States) was used. Fractions were eluted with water at the rate of $0.6 \mathrm{~mL} / \mathrm{min}$ at $25^{\circ} \mathrm{C}$ and detected by a RID 6A Refractive Index Detector (Shimadzu, Japan). Sugar standards, including D-glucose, D-fructose, sucrose (Sigma, United States), and isomaltulose (Wako pure Chemical Industries, Japan) were used.

\section{Enzyme production and purification}

The yeast $P$. pastoris X33 harboring K.SI36.PalI gene was grown in $50 \mathrm{~mL}$ of BMG $(100 \mathrm{mM}$ potassium phosphate, $\mathrm{pH} 6.0,1.34 \% \mathrm{YNB}, 0.4 \mathrm{ppm}$ biotin, $1 \%$ glycerol) at $28^{\circ} \mathrm{C}$ with shaking at $150 \mathrm{rpm}$ for $24 \mathrm{~h}$. The cells were harvested by centrifugation and reinoculated in $200 \mathrm{~mL}$ expression medium BMM and incubated at the same condition. For remaining inducing state for the recombinant enzyme synthesis, $0.5 \%$ methanol was added every $24 \mathrm{~h}$. After $96 \mathrm{~h}$, the fermentation broth was centrifuged at $6000 \times \mathrm{g}$ for 30 min at $4^{\circ} \mathrm{C}$ and cells were discarded. The obtained supernatant was concentrated using Viva flow 200, 30 kDa MWCO (Sartorius, Germany). The enzyme was further purified using Superdex 200 (GE Healthcare, United States) gel filtration. Sample of $5 \mathrm{~mL}$ was loaded into XK 26/40 column (GE Healthcare, United States) and eluted with $20 \mathrm{mM}$ sodium phosphate buffer, $\mathrm{pH} 7.0$ at the rate of $1 \mathrm{~mL} \cdot \mathrm{min}^{-1}$ with column temperature maintained at about $10^{\circ} \mathrm{C}$. Fractions of 5 $\mathrm{mL}$ were collected and tested for sucrose isomerase activity.

\section{Effect of pH and temperature}

Purified sucrose isomerase was used to assess the effect of $\mathrm{pH}$ and temperature on the activity and the stability of the enzyme. Testing the enzyme activity at different temperatures $\left(20-80^{\circ} \mathrm{C}\right)$ was carried out in 20 $\mathrm{mM}$ sodium phosphate buffer, $\mathrm{pH}$ 7.0. For testing the effect of $\mathrm{pH}$, following buffer systems $(50 \mathrm{mM})$ were used: $\mathrm{pH} \mathrm{4,} \mathrm{5,} 6$ - citrate-phosphate; $\mathrm{pH}$ 7, 8 - sodium phosphate; pH 9, 10 - glycine sodium hydroxide. To determine thermostability, enzyme was incubated at $40,50,60^{\circ} \mathrm{C}, \mathrm{pH} 7.0$ and the remaining activity was measured at different time intervals. Similarly, for assessing the $\mathrm{pH}$ stability, the enzyme was incubated at different $\mathrm{pHs}$, but the temperature was kept at $40^{\circ} \mathrm{C}$.

\section{Enzyme kinetic}

Conversion kinetics were studied using sucrose substrate concentrations of 20 and $40 \%$. An initial sucrose isomerase activity of $10 \mathrm{U} \cdot \mathrm{mL}^{-1}$ was used and the reaction was carried out at $\mathrm{pH} 7.0,40^{\circ} \mathrm{C}$ in a volume of $5 \mathrm{~mL}$. Samples collected at different time intervals were heat-treated $\left(100^{\circ} \mathrm{C}, 10 \mathrm{~min}\right)$ then analyzed by DNS and HPLC.

\section{RESULTS}

\section{Cloning and sequence analysis of K.SI36.PalI gene}

The PCR amplification of K.SI36.PalI gene from genomic DNA of $K$. singaporensis ISB36 using primers SI12-EcoRI and SI13-XbaI-R yielded in a fragment of about 1700 bp (Figure 1(a)). After ligating with $p P I C Z \alpha A$ and transforming into $E$. coli $\mathrm{DH} 5 \alpha$, the insert was sequenced using the primers $\alpha$-factor and 3'-AOX1. The closest GenBank sequence was AAK82938 of $K$. singaporensis LX3 with 99,94\% similarity (differ 1 nucleotide over 1713 nucleotides in mature gene). There was a nucleotide substitution leading to the alteration from Ser at the amino acid position 342 of $K$. singaporensis LX3 to Phe. In our construct, the native 28 amino acid signal peptide sequence was replaced by the $\alpha$-factor sequence of the plasmid. The mature sequence of the K.SI36.PalI gene was expected to differ from $K$. singaporensis LX3 also by two amino acid (Glu and Phe) introduced with the primer (EcoRI recognition site) at the N-terminus. The predicted protein would have 572 amino acids and with estimated molecular weight of $67.46 \mathrm{kDa}$, pI of 6.55. The enzyme was expected to have a low level of glycosylation as there was only one potential glycosylation site at 466Asn identified.

After transformation to $P$. pastoris $\mathrm{X} 33,24$ yeast clones were selected and tested for sucrose isomerase activity. All selected clones expressed sucrose isomerase activity after $72 \mathrm{~h}$ of cultivation. The mean activity was $13.4 \mathrm{U} \cdot \mathrm{mL}^{-1}$ and the maximum activity obtained was 32 U.mL $L^{-1}$ (Figure 2). 


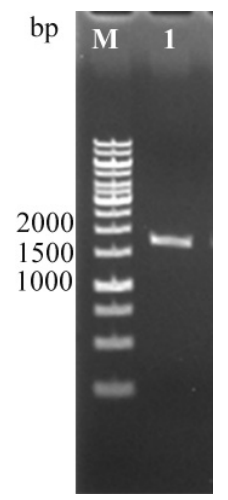

(a)

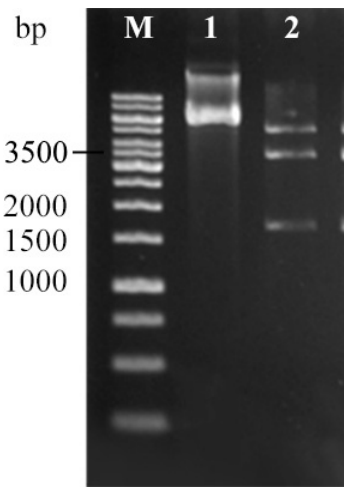

(b)

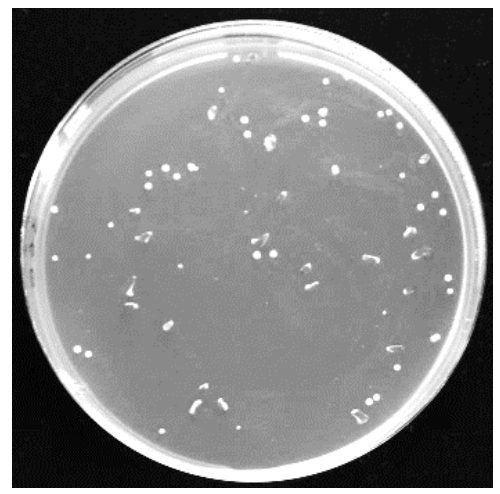

(c)

Figure 1. Cloning of K.SI36.Pall gene from K. singaporensis ISB36. (a): PCR product amplified with primers SI12-EcoRI and SI13-Xbal-R. (b): pPICZaA containing K.SI36.Pall gene (1) before and (2) after digestion with EcoRI and Xbal; (c): P. pastoris clones growing on YPD-zeocin agar.

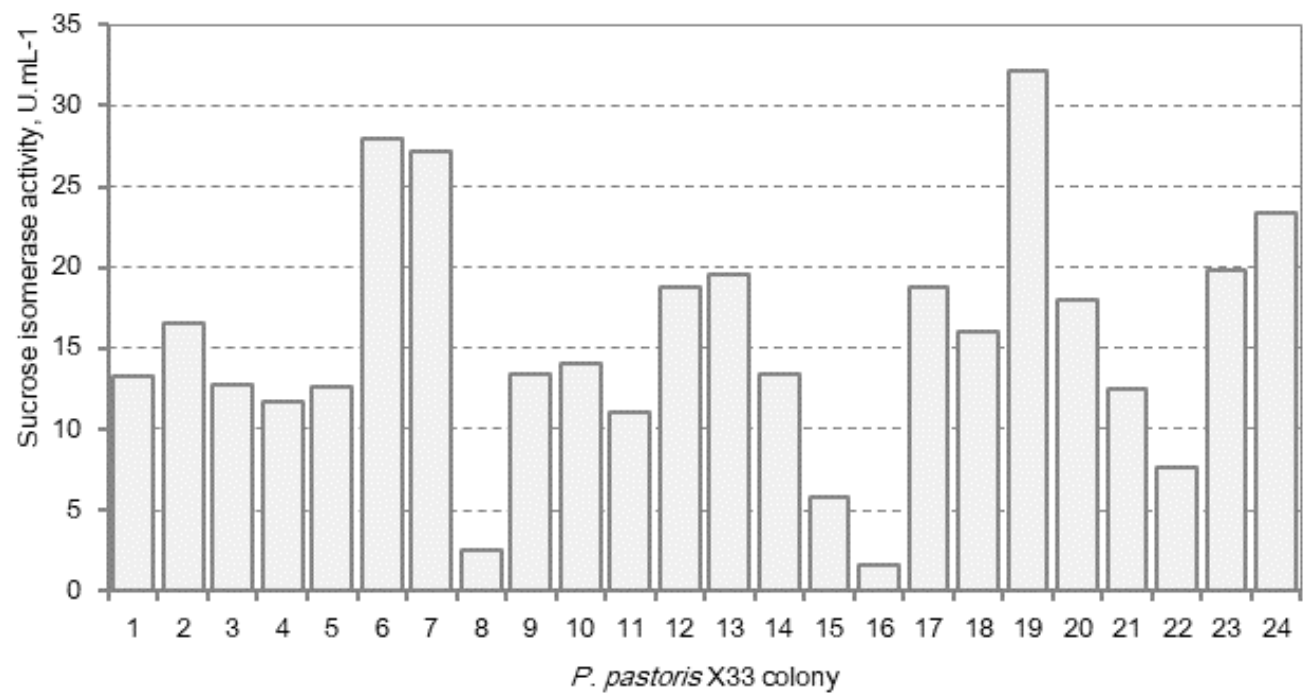

Figure 2. Screening of $P$. pastoris $\mathrm{X} 33$ clones containing K.S/36.Pall gene for sucrose isomerase activity.

\section{Fermentation and purification of the enzyme}

Based on initial screening, clone X33.SI36\#7 was selected from top high sucrose isomerase activity (\#19, \#6, \#7 and \#24) for enzyme expression and characterization. The yeast was cultivated in a $2 \mathrm{~L}$ fermentor with $\mathrm{pH}$ maintained at 5.0 and dissolved oxygen above $10 \%$. After $96 \mathrm{~h}$, wet biomass reached 90 g. $\mathrm{L}^{-1}$ and extracellular protein concentration was $10 \mu \mathrm{g} \cdot \mathrm{mL}^{-1}$. Sucrose isomerase activity of the culture supernatant was 36.6 U. $\mathrm{mL}^{-1}$. After 10-fold concentration, the activity of 300.8 U.mL $L^{-1}$ was achieved. After gelfiltration purification, the sucrose isomerase activity was $46.5 \mathrm{U} \cdot \mathrm{mL}^{-1}$. SDS-PAGE indicated the presence of one protein band just below the 66.2 $\mathrm{kDa}$ marker protein, slightly smaller than the predicted size $(67.46 \mathrm{kDa})$. The absence of the smear zone above the band indicated a low level of glycosylation (Figure 3 ). 


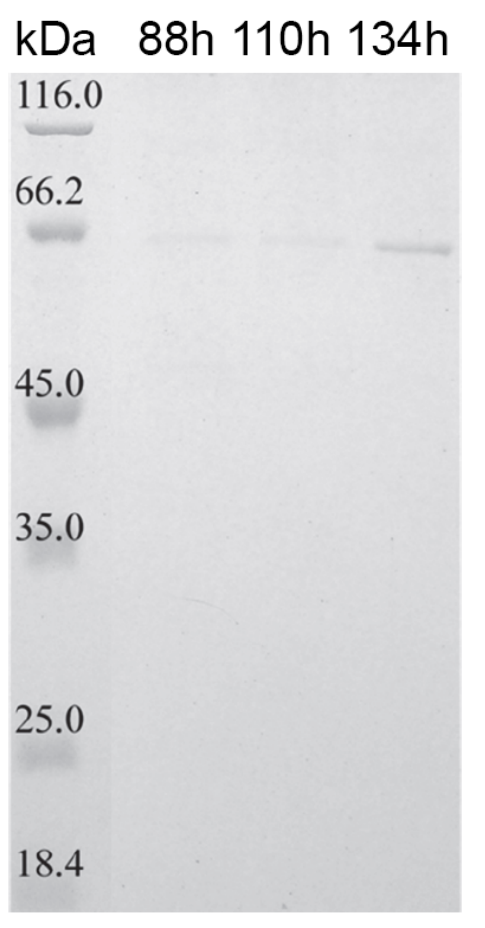

(a)

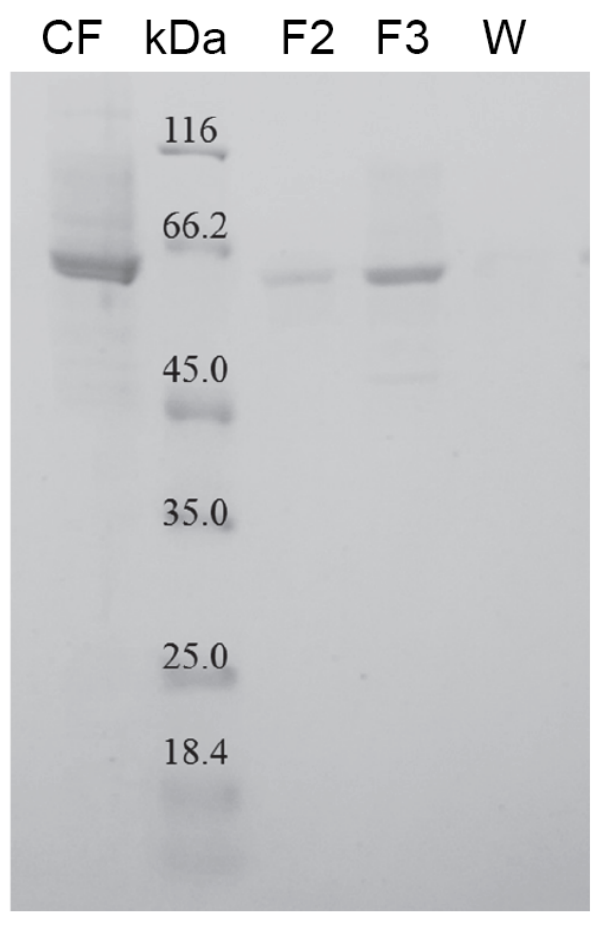

(b)

Figure 3. SDS-PAGE analysis of sucrose isomerase. (a): Culture supernatant after 88, 110 , and $134 \mathrm{~h}$ of fermentation; (b): CF - supernatant after concentration; F2, F3, W - fractions 2, 3 and waste of gel-filtration chromatography; kDa - standard protein markers and sizes in $\mathrm{kDa}$.

\section{Effect of temperature}

Sucrose isomerase of $K$. singaporensis ISB36 expressed in $P$. pastoris $\mathrm{X} 33$ showed maximum activity at $40^{\circ} \mathrm{C}$. At higher temperatures, the enzyme rapidly lost the function. At $50^{\circ} \mathrm{C}$ and $60^{\circ} \mathrm{C}$ the activity was only $20 \%$ and $7 \%$ of that at $40^{\circ} \mathrm{C}$, respectively. The enzyme was thermolabile with the half-life less than $10 \mathrm{~min}$ at $50^{\circ} \mathrm{C}$, and less than $1 \mathrm{~h}$ at $40^{\circ} \mathrm{C}$. The data obtained by this study agree well with the previous reports. Enzyme sucrose isomerase synthase from K. singaporensis LX3 (K.LX3.Pall) was most active at $35-40^{\circ} \mathrm{C}$ and at $50^{\circ} \mathrm{C}$ and $60^{\circ} \mathrm{C}$, the activity was only $47 \%$ and $6 \%$ of the optimum (Zhang et al., 2002). Similarly, sucrose isomerase from Enterobacter sp. FMB-1 has an optimum temperature of $45^{\circ} \mathrm{C}$ and lost activity at $60^{\circ} \mathrm{C}$ (Lee et al., 2011b).

\section{Effect of pH}

The enzyme had no activity outside the $\mathrm{pH} 5.0$ to $\mathrm{pH} 10.0$ range (Figure 5) and it functioned best at $\mathrm{pH}$
7.0. At $\mathrm{pH} 6.0$ or $\mathrm{pH} 8.0$, the activity of the enzyme reduced by $35 \%$. At low temperature, the enzyme was rather stable at different $\mathrm{pHs}$ after $72 \mathrm{~h}$ of incubation at $4{ }^{\circ} \mathrm{C}$ in the buffers with $\mathrm{pH} 5.0$ and $\mathrm{pH} 7.0$, the residual activity of the enzyme detected was $75 \%$ and $80 \%$, respectively. At the temperature optimum $\left(40^{\circ} \mathrm{C}\right)$, the enzyme lost activity rapidly when incubated in the buffer with $\mathrm{pH} 5.0$ and with a lesser extent at $\mathrm{pH} 6.0$ and $\mathrm{pH} 7.0$.

\section{Reaction kinetic}

The conversion of sucrose into isomaltulose by recombinant sucrose isomerase was rapid and efficient. After $2 \mathrm{~h}$ of incubation with $10 \mathrm{U} \cdot \mathrm{mL}^{-1}$ sucrose isomerase, $60 \%$ of sucrose in the $40 \%$ sucrose solution was converted into isomaltulose and after 6 $\mathrm{h}$, the conversion was nearly complete (94\%) (Figure 6). HPLC analysis indicated the presence of a minor amount of D-glucose, D-fructose, and trehalulose (4$5 \%$ in total, data not shown). 

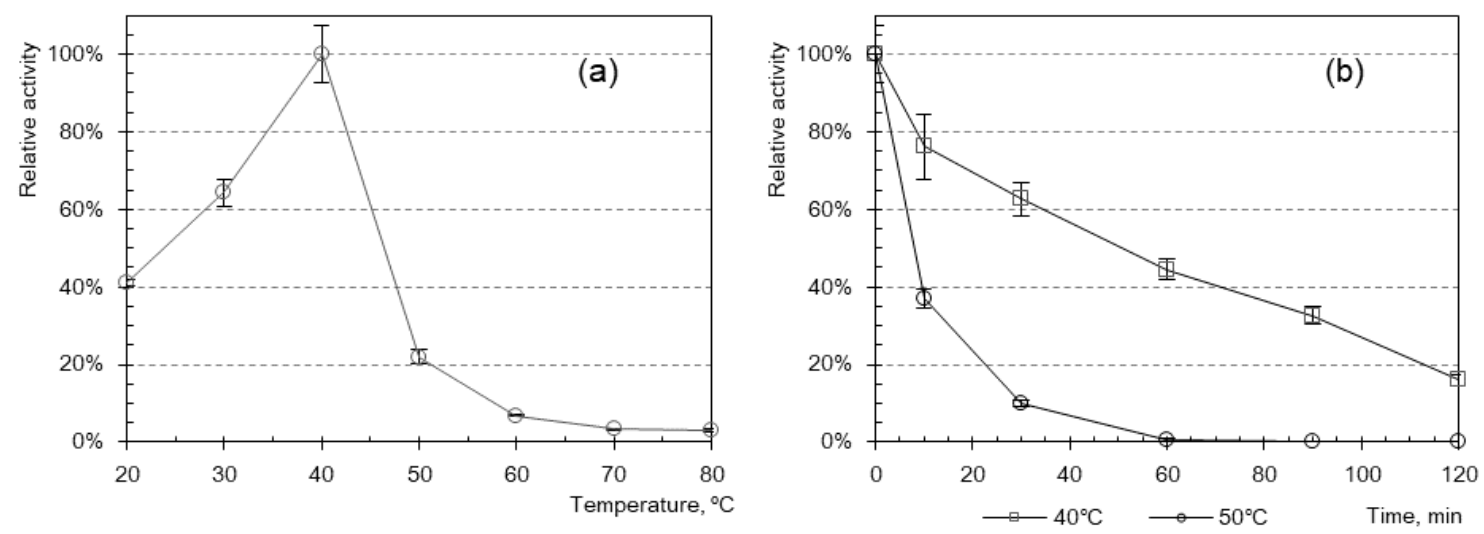

Figure 4. The effect of temperature on sucrose isomerase activity. (a): activity at different temperatures; (b): thermostability of the enzyme.
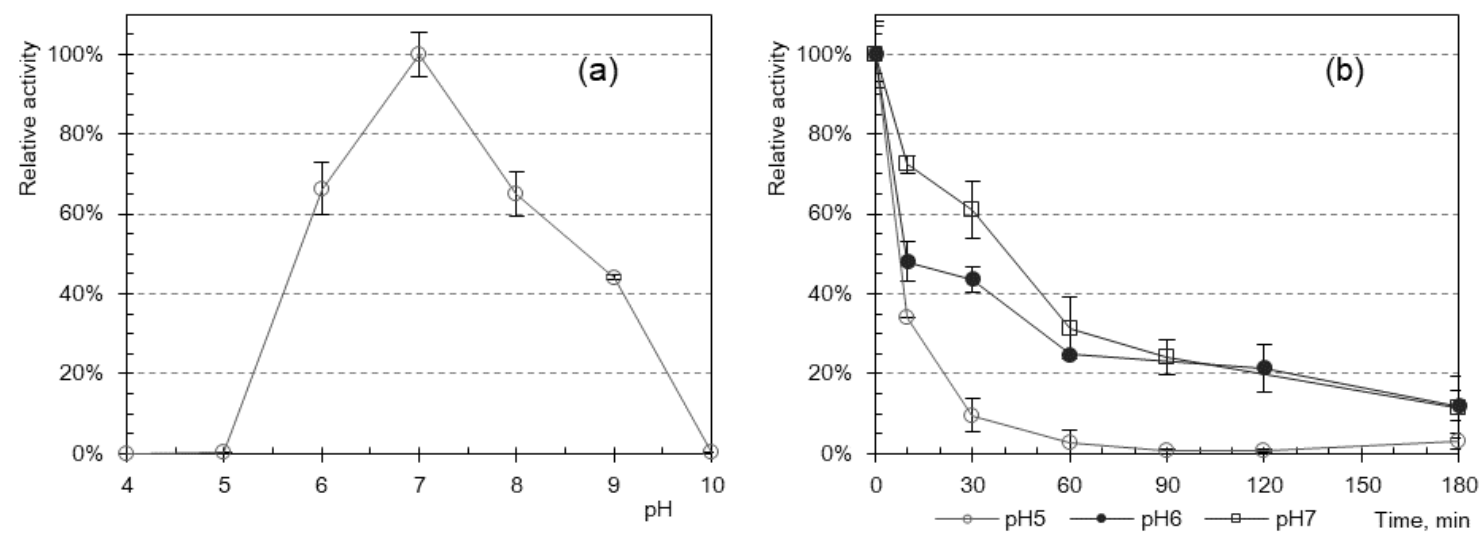

Figure 5. The effect of $\mathrm{pH}$ on sucrose isomerase activity. (a): activity at different pHs; (b): the stability of enzyme at different pHs.

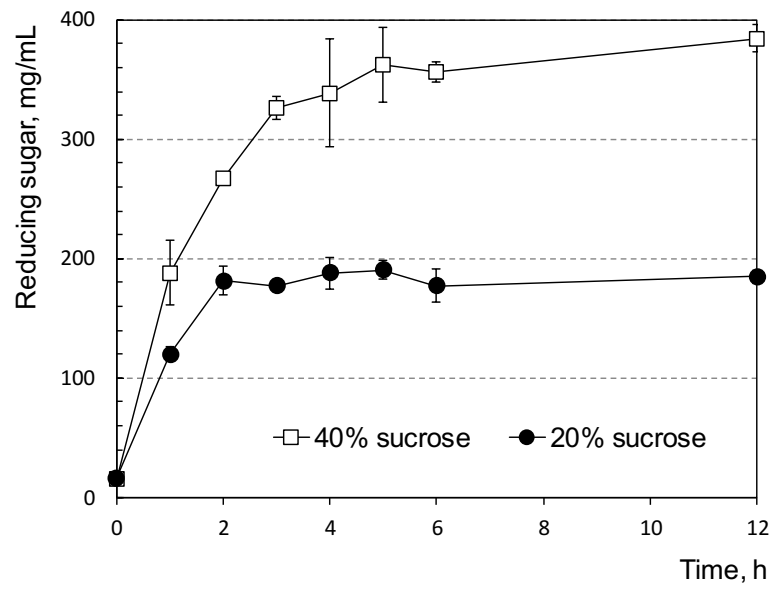

Figure 6. Kinetic of isomerization at different initial sucrose concentrations. 


\section{CONCLUSION}

With one amino acid substitution, sucrose isomerase obtained from $K$. singaporensis ISB36 was nearly identical to the previously studied of $K$. singaporensis LX3 (Zhang et al., 2002; Zhang et al., 2003). The enzyme expressed in $P$. pastoris demonstrated similar properties with the enzyme expressed in $E$. coli in terms of $\mathrm{pH}$, temperature optima and stability. The recombinant enzyme could efficiently convert sucrose into isomaltulose with a minor amount (less than 5\%) of by-products. This is the first report on the expression of sucrose isomerase using $P$. pastoris system. The use of recombinant sucrose isomerase could reduce the risk associated with endotoxin and formaldehyde in isomaltulose production.

Acknowledgement: This study was financed by grant \#04.2016/CNSHCB from the Ministry of Industry and Trade of Vietnam.

\section{REFERENCES}

BeMiller JN (2019) Oligosaccharides. In Carbohydrate Chemistry for Food Scientists: 49-74.

Cha J, Jung JH, Park SE, Cho MH, Seo DH, Ha SJ, Park CS (2009) Molecular cloning and functional characterization of a sucrose isomerase (isomaltulose synthase) gene from Enterobacter sp. FMB-1. J Appl Microbiol 107(4): 11191130.

Ghose TK (1987) Measurement of cellulase activities. Pure Appl Chem59(2): 257-268.

Goulter KC, Hashimi SM, Birch RG (2012) Microbial sucrose isomerases: Producing organisms, genes and enzymes. Enzyme Microb Technol 50(1): 57-64.

Kawaguti HY, Sato HH (2010) Isomaltulose production by free cells of Serratia plymuthica in a batch process. Food Chem 120(3): 789-793.

Krastanov A, Yoshida T (2003) Production of palatinose using Serratia plymuthica cells immobilized in chitosan. $J$ Ind Microbiol Biotechnol 30(10): 593-598.

Lee GY, Jung JH, Seo DH, Hansin J, Ha SJ, Cha J, Park CS (2011a) Isomaltulose production via yeast surface display of sucrose isomerase from Enterobacter sp. FMB-1 on Saccharomyces cerevisiae. Bioresour Technol 102(19): 9179-9184.

Lina BR, Jonker D, Kozianowski G (2002) Isomaltulose
(Palatinose 1): a review of biological and toxicological studies. Food and Chemical Toxicol 40: 1375-1381.

Mu W, Li W, Wang X, Zhang T, Jiang B (2014a) Current studies on sucrose isomerase and biological isomaltulose production using sucrose isomerase. Appl Microbiol Biotechnol 98(15): 6569-6582.

Mu W, Li W, Wang X, Zhang T, Jiang B (2014b) Current studies on sucrose isomerase and biological isomaltulose production using sucrose isomerase. Appl Microbiol Biotechnol 98(15): 6569-6582.

Nguyễn Thanh Thủy, Nguyễn T Hoa Mai, Đinh T Mỹ Hằng, Vũ Nguyên Thành (2013) Công nghệ sản xuất isomaltulose từ sucrose sử dụng vi khuẩn Enterobacter sp. ISB-25. Tạp chi Khoa học và Công nghệ 51(2): 173-184.

O'Donnell K, Kearsley M (2012) Sweeteners and sugar alternatives in food technology. John Wiley \& Sons.

Orsi DC, Sato HH (2016) Isomaltulose production using free and immobilized Serratia plymuthica cells. Afr $J$ Biotechnol 15(20):835-842.

Park JY, Jung JH, Seo DH, Ha SJ, Yoon JW, Kim YC, Park CS (2010) Microbial production of palatinose through extracellular expression of a sucrose isomerase from Enterobacter sp. FMB-1 in Lactococcus lactis MG1363. Bioresour Technol 01(22): 8828-8833.

Tiefenbacher KF (2017) Technology of main ingredientssweeteners and lipids. In Wafer and Waffle: 123-225.

Veronese T, Perlot P (1998) Proposition for the biochemical mechanism occurring in the sucrose isomerase active site. FEBS Lett 441(3): 348-352.

Véronèse T, Perlot P (1999) Mechanism of sucrose conversion by the sucrose isomerase of Serratia plymuthica ATCC 15928. Enzyme Microb Technol 24(5-6): 263-269.

Wei Y, Liang J, Huang Y, Lei P, Du L, Huang R (2013) Simple, fast, and efficient process for producing and purifying trehalulose. Food Chem 138(2-3):1183-1188.

Xu Z, Li S, Li J, Li Y, Feng X, Wang R, Zhou J (2013) The structural basis of Erwinia rhapontici isomaltulose synthase. PLOS ONE 8(9).

Zhang D, Li N, Lok SM, Zhang LH, Swaminathan K (2003) Isomaltulose synthase (PalI) of Klebsiella sp. LX3: Crystal structure and implication of mechanism. $J$ Biol Chem 278(37): 35428-35434.

Zhang D, Li X, Zhang LH (2002) Isomaltulose synthase from Klebsiella sp. strain LX3: Gene cloning and characterization and engineering of thermostability. Appl Environ Microbiol 68(6): 2676-2682. 


\title{
TÁCH DÒNG GEN MÃ HÓA SUCROSE ISOMERASE TÙ KLEBSIELLA SINGAPORENSIS ISB-36 VÀ BIỄU HIỆN TRÊN PICHIA PASTORIS
}

\author{
Cao Xuân Bách, Đặng Thị Kim Anh, Nguyễn Thanh Thủy, Trương Tú Anh, Nguyễn Thị Diệu Linh, Vũ \\ Nguyên Thành
}

Viện Công nghiệp Thực phẩm, 301 Nguyễn Trãi, Thanh Xuân, Hà Nội, Việt Nam

\section{TÓM TẮT}

Với những lợi ích sức khỏe như chỉ số đường huyết thấp, không gây sâu răng, phù hợp với trẻ sơ sinh, người già và bệnh nhân tiểu đường, isomaltulose được coi là một chất ngọt thay thế đây hứa hẹn cho sucrose. Do sự hiện diện của endotoxin liposaccharide trong Serratia plymuthica CBS 574.44, một vi khuẩn Gram âm, và formaldehyde tồn dư, tinh chế isomaltulose đòi hỏi được kiểm soát chặt chẽ trong công nghiệp. Để giảm chi phí tinh chế sản phẩm, chúng tôi đề xuất sử dụng sucrose isomerase tái tổ hợp trong sản xuất isomaltulose. Gen trưởng thành mã hóa enzyme sucrose isomerase (K.SI36.PalI) từ Klebsiella singarporensis ISB 36 phân lập từ ấu trùng xén tóc ở Việt Nam được biểu hiện trong Pichia pastoris X33. Gen K.SI36.PalI tương đồng với trình tự AY040843.1 của Klebsiella sp. LX3 ngoại trừ một nucleotide tại vị trí $\mathrm{C}^{1025}$ trong AY040843.1, được thay bằng $\mathrm{T}^{1025}$ trong trình tự của K.SI36.PalI. Điều này dẫn đến sự khác biệt một amino acid thành phần (342Ser thành 342Phe). Thêm vào đó, hai amino acid Glu và Phe được quan sát thấy ở đầu $\mathrm{N}$. Khối lượng phân tử tính toán của sucrose isomerase từ K.SI36.PalI là $67,46 \mathrm{kDa}$, pI là 6,55. Một vị trí glycosyl hóa tiềm năng tại 466Asn. Hoạt tính sucrose isomerase trong canh trường đạt $36,6 \mathrm{U}_{\mathrm{m}} \mathrm{mL}^{-1}$ trong bình tam giác $1 \mathrm{~L}$. Enzyme tinh chế hoạt động mạnh nhất ở $\mathrm{pH} 7,0$ và $40^{\circ} \mathrm{C}$. Ở điều kiện tối ưu, enzyme chuyển hóa $94 \%$ sucrose trong dung dịch sucrose $40 \%$ thành isomaltulose trong vòng 6 giờ. Đây là nghiên cứu đầu tiên về biểu hiện của sucrose isomerase ở $P$. pastoris và kết quả đã cho thấy sự chuyển hóa hiệu quả của enzyme tái tổ hợp.

Từ khoá: chất ngọt thục phẩm, isomaltulose, Klebsiella, Pichia pastorsis, enzyme tái tổ hợ, sucrose isomerase. 